$\underline{\text { Research Article }}$

\title{
Relationship between Assertive Communication and Cyber-bullying in Adolescents
}

\section{Hubungan Komunikasi Asertif dengan Cyber-bullying pada Remaja}

\author{
Ira Kusumawaty ${ }^{1}$, Yunike Yunike ${ }^{2}$, Sujati Ni Ketut ${ }^{3}$ \\ ${ }^{1}$ Department of Mental Health Politeknik Kesehatan Kemenkes Palembang \\ ${ }^{2}$ Department of Pediatric Politeknik Kesehatan Kemenkes Palembang \\ ${ }^{3}$ Department of Medical Surgical Nursing Politeknik Kesehatan Kemenkes Palembang
}

\begin{abstract}
The mandatory use of online facilities during the Covid-19 period has a great opportunity to increase the problem of cyber bullying at all levels of education. The concept of assertiveness cannot be separated from cyber bullying and it is known that communicating assertively can prevent cyber bullying even though it is difficult to implement. The complexity of the psychological problems of victims of cyber bullying requires comprehensive management. This analytical descriptive study with a cross sectional approach aims to analyze the relationship between assertive communication and cyber bullying by involving 151 student participants and high school students in Palembang. The data was collected using an assertive scale and a cyber-bullying scale, which was distributed online using a Google form. From Kendall's tau-b statistical test, it is known that there is a relationship between assertive communication and cyber bullying $(p=0.026)$. It is recommended that the education sector implement self-awareness, empathy, assertive communication and conflict resolution training to prevent the increasing number of cyber bullying's victim. The academic and managerial sectors are expected to facilitate promotion through educational media about using online facilities intelligently by respecting human dignity.
\end{abstract}

Keywords: Adolescents, assertive communication, cyber bullying

\begin{abstract}
ABSTRAK
Keharusan penggunaan fasilitas online selama periode Covid-19 berpeluang besar untuk meningkatkan permasalahan cyber bullying di semua jenjang pendidikan. Konsep asertif tidak terlepas dari cyber bullying dan diketahui bahwa berkomunikasi secara asertif dapat mencegah terjadinya cyber bullying walaupun sulit dalam penerapannya. Penelitian deskriptif analitik dengan pendekatan cross sectional ini bertujuan untuk menganalisis hubungan antara komunikasi asertif dengan cyber bullying dengan melibatkan 151 partisipan mahasiswa dan siswa sekolah menengah atas di Palembang. Pengumpulan data dilakukan dengan menggunakan skala asertif dan skala cyberbullying, yang didistribusikan secara online menggunakan formulir google. Analisis Kendall's tau-b digunakan untuk mengetahui hubungan antara komunikasi asertif dengan cyber bullying pada tingkat kepercayaan 95\%. Berdasarkan hasil analisis tau-b Kendall didapatkan hasil hubungan antara komunikasi asertif dengan cyber bullying, dan p-value 0,026. Sangat penting untuk meningkatkan kemampuan komunikasi asertif di kalangan remaja guna mencegah terjadinya cyber bullying. Pemanfaatan sosial media merupakan kiat jitu dalam menyampaikan aplikasi yang memuat informasi mengenai dampak cyber bullying serta cara melakukan komunikasi asertif. Disarankan agar pihak pendidikan melaksanakan pelatihan kesadaran diri, empati, berkomunikasi asertif dan resolusi untuk mengatasi konflik harus diterapkan untuk mencegah semakin bertambahnya jumlah korban cyberbullying. Sektor akademik dan manajerial diharapkan dapat memfasilitasi promosi melalui media pendidikan tentang penggunaan fasilitas online secara cerdas dengan menghormati harkat dan martabat manusia.
\end{abstract}

Kata Kunci: Cyberbullying, komunikasi asertif, remaja

Correspondence: Ira Kusumawaty. Department of Mental Health Politeknik Kesehatan Kemenkes Palembang, Jl. Merdeka No. $76-78$ Palembang Tel. (0711)351081 Email: irakusumawaty@poltekkespalembang.ac.id

DOI: http://dx.doi.org/10.21776/ub.jkb.2021.031.04.7 


\section{INTRODUCTION}

During the Covid-19 era, the use of online facilities was a fortune because of restrictions on interaction to prevent the spread of Covid-19, including in Palembang. One of the impacts that can occur from communicating too often online is cyber bullying. Big problems can occur due to cyber bullying, including: low self-esteem (1-3), even suicide (4-5). Many factors can cause cyber bullying, including the inability to express opinions assertively $(6,7)$. A person's inability to express his opinion assertively will result in bullying behavior. Assertive behavior is the behavior of individuals who can do something on the basis of their own wishes without coercion from others, enforce their personal rights without overriding the rights of others, and are able to express feelings comfortably. Assertive behavior is associated with components of request, rejection, self-expression, praise, a role in the conversation (8-11).

The inability to show assertive communication can lead to bullying (6). The dynamics of factors that encourage the inability to express opinions assertively can come from individuals and also family environmental factors. Socioeconomic conditions can cause low self-esteem in children due to the inability of the family to meet their daily needs, or even vice versa. Adolescents who come from families who are in financial terms have a tendency to bully other teenagers (12-14). The use of social media differs between women and men $(7,13,15-17)$. The disturbances experienced by adolescent victims of cyber bullying are psychological and emotional disorders, namely feelings of fear, feelings of terror, anxiety, suffering, sadness, stress and depression symptoms (1820). Decreases in concentration and academic scores also occur. On the psychosocial aspect, adolescents feel isolated, lonely, exclusion and even social rejection (2123).

Bullying can be in the form of physical, verbal, social and relational bullying (24). Repeated use of online social media provides an opportunity for the emergence of cyber bullying behavior unconsciously (25). This can occur due to the inability of teenagers to refuse written wishes from friends or anyone else to do something (26). The components of cyber bullying include: reduction, power imbalance, willfulness and aggression $(22,27)$. Internal motivation in cyber bullying distracts feelings, takes revenge, makes feelings better, feels boredom, protection, jealousy, gets approval and anonymity $(28,29)$. Given the dangerous impact of cyber bullying, it encourages researchers to examine the relationship between assertive behavior and other enabling factors with cyber bullying behavior. This study objectives to determine the relationship between assertive communication and cyber bullying behavior in adolescents. The difference between this study and previous research is the data collection process using the online Google form facility. The novelty in this research is more devoted to the study of the communication aspect of the assertive component during the Covid-19 pandemic, not to assertive behavior in general.

\section{METHOD}

This quantitative study aims to determine the relationship between assertive communication variables and other characteristic factors with cyber bullying in adolescents.
This research has passed the ethical review of the Ethics Committee Politeknik Kesehatan Palembang. The population and sample of this study were adolescents aged $15-25$ years and live in Palembang.

Data collection was carried out by using a questionnaire distributed via Google form and participants' names are written in the initials only. In the Google form, informed consent has been listed that explains the purpose of the study and guarantees the confidentiality of information submitted by participants. The questionnaire can only be filled out by participants if the participants are willing to be involved in the research. The distribution of the questionnaire was initiated by distributing it through the Sapp group and then redistributed to other What Sapp groups. Participants who are willing to be involved in the research have been compensated for their involvement.

Measurement of assertive communication is carried out using 50 assertive scales; cyber bullying is measured using 64 cyber bullying scales consisting of favorable and unfavorable statements. All statements are measured using an answer choice scale starting to strongly agree, agree, disagree and strongly disagree. The questionnaire's validity and reliability were tested on 30 participants who had met the inclusion criteria and were not involved in the study. The results of the questionnaire trial gave the following results, after the validity test was carried out; it was found that the invalid statements were questions number $1,6,10,12,15,20$. Then the reliability test was carried out on 110 valid questions and the Cronbach's alpha values for the assertive communication scale and the cyber bullying scale, respectively, are 0.733 and 0.739 . It can be concluded that all questions are reliable. The statements in the questionnaire were distributed to the participants so that in the end 151 participants were collected and sent a fully filled Google form.

The results of data collection were analyzed by univariate and bivariate. Univariate analysis was conducted to determine the percentage of assertive communication and cyber bullying variables. Kendall's tau-b analysis was used when analyzing data in a bivariate manner and the selection of this statistical test is because the data are not normally distributed. The analysis process was carried out at a $95 \%$ confidence level.

\section{RESULTS}

The Characteristic of respondent in this research shown in table 1 . The majorities of participants aged $15-18$ years, with the status of students, is the first children, female, living together with parents and have high assertive communication. As the dependent variable, the majority of participants have low levels of cyber bullying behavior.

Table 1. Participant's characteristic

\begin{tabular}{|c|c|c|c|c|}
\hline No. & Variable & Category & $\begin{array}{l}\text { Frequency } \\
\text { (n) }\end{array}$ & $\begin{array}{l}\text { Percentage } \\
\text { (\%) }\end{array}$ \\
\hline \multirow[t]{2}{*}{1.} & Age (years) & $15-18$ & 106 & 70.2 \\
\hline & & $19-25$ & 45 & 29.8 \\
\hline \multirow[t]{2}{*}{2.} & Educational status & Student & 37 & 24.5 \\
\hline & & College student & 114 & 75.5 \\
\hline \multirow[t]{3}{*}{3.} & Participants' birth & The oldest child & 65 & 43.0 \\
\hline & order & Middle child & 49 & 32.5 \\
\hline & & The youngest child & 37 & 24.5 \\
\hline
\end{tabular}


Table 1. Participant's characteristic

\begin{tabular}{llcc}
\hline No. Variable & Category & $\begin{array}{c}\text { Frequency } \\
\text { (n) }\end{array}$ & $\begin{array}{c}\text { Percentage } \\
\text { (\%) }\end{array}$ \\
\hline 4. Residence & Rent & 41 & 27.2 \\
& With parents & 97 & 64.2 \\
& With relatives & 13 & 8.6 \\
5. Gender & Male & 39 & 25.8 \\
& Female & 112 & 74.2 \\
6. Parents' & Permanent employee & 85 & 56.3 \\
& employment status & 66 & 43.7 \\
& Temporary & & \\
\hline Total & employees & 151 & 100 \\
\hline
\end{tabular}

Table 2. Percentage of participant assertive communication and cyber bullying

\begin{tabular}{lllcr}
\hline No. & Variables & Category & $\begin{array}{c}\text { Frequency } \\
\text { (n) }\end{array}$ & $\begin{array}{c}\text { Percentage } \\
\text { (\%) }\end{array}$ \\
\hline 1. & Assertive & Low & 5 & 3.3 \\
& communication & Moderate & 21 & 13.9 \\
& & High & 81 & 53.6 \\
& & Very high & 44 & 29.1 \\
2. Cyber bullying & Low & 74 & 49.0 \\
& & Moderate & 18 & 11.9 \\
& & High & 52 & 34.4 \\
& Very high & 7 & 4.6 \\
\hline Total & & 151 & 100 \\
\hline
\end{tabular}

Table 3. Relationship between demographic data and assertive communication with cyber bullying

\begin{tabular}{llc}
\hline No. & \multicolumn{1}{c}{ Independent Variable } & p-value \\
\hline 1. & Age & 0.223 \\
2. & Educational status & 0.017 \\
3. & Gender & 0.001 \\
4. & Participants' birth order & 0.002 \\
5. & Residence & 0.013 \\
6. & Parents' employment status & 0.004 \\
7. & Assertive communication & 0.026 \\
\hline
\end{tabular}

Table 3 shows the percentage of participant assertive communication and cyber bullying. Almost half of the respondents have an experience on the assertive communication and low cyber bullying. According to Kendall's tau-b statistical test, it is known that there is a relationship between assertive communication and cyber bullying with a $\mathrm{p}$ value 0.026 .

\section{DISCUSSION}

Adolescence is a transitional age from childhood to adulthood, with its distinctive characteristics. During their development, adolescents undergo changes towards the maturity process towards adulthood so that it determines mental health development (30). The Covid-19 condition has made its own contribution to teenagers in communicating and interacting, especially in utilizing the facilities offered by social media. Communicating without interacting is possible to reduce someone's assertiveness so that it has the potential to generate cyber bullying behavior. As the results of the study suggest that assertiveness can be improved by paying attention to verbal and non-verbal responses when communicating $(9,31,32)$. Assertive has an effect on self-confidence, psychological conditions and stress (33-35).

A person's lack of self-confidence can be manifested in the opposite shape, namely by bullying his friends. Doing cyber bullying initiates a person to experience powerful and require to intimidate as a form of revenge, the desire to dominate so that their self-esteem increases after being able to dominate others (37). This study provides results that a person's ability to be able to communicate assertively is closely related to the emergence of cyber bullying behavior (36). This study shows that a person's ability to communicate assertively is closely related to the emergence of cyber bullying behavior. Someone who is not able to communicate assertively will tend to show cyber bullying behavior. However, the process of forming assertive communication does not take place suddenly, it requires a process of enhancement and habituation. Emerging the ability to interrelate every day to change communication habits that are different from previous habits requires a strong effort from oneself accompanied by the support of the surrounding environment. When teenagers cannot get used to communicating assertively, there will be a tendency to carry out cyber bullying due to dissatisfaction with themselves.

Adolescence is a period of rapid physical, social and psychological improvement. These changes go hand in hand with the ability to adapt quickly to technological advances. If it is not balanced with good emotional management, it is not impossible that the incidence of cyber bullying in adolescents enhances along with technological advances. During the Covid-19 episode there was an increase in the level of adolescence dependence on interacting in cyberspace. The development of information, technology bridges interactions between adolescents and it is not impossible for cyber bullying to occur. Especially throughout the Covid-19 pandemic, direct interaction has become a very expensive activity, the lack of interaction makes a person dull towards the feelings of the other person. Communicating through written language does not involve much of a person's emotional effects. This is possible because the other person is not able to express his feelings when communicating. Expressing feelings takes time to convey them in writing; the more outpouring will be delivered. However, it is possible that some people have the ability to convey their feelings well in writing $(26,37)$. Communication is very much influenced by the feeling element. The accomplishment in interacting is characterized by the ability of the friends communicate to understand the other person's feelings and to be aware of the psychological condition when speaking. Often the facts show that understanding the feelings of the friends communicate takes precedence over the information to be conveyed. It's a very good thing when we try to get to know the psychological condition of someone with whom we interact. However, the psychological condition flows into every meaning of the information conveyed (37).

Success in interacting is also thought to be related to the ability to be assertive. When someone is assertive, the empathy component is involved. Expressing opinions 
assertively should deliberate comprehending the psychological condition of the other person. As it is known that assertiveness is an attitude, behavior, communication about something that is not in accordance with one's own desires, therefore the person spoken to is expected to recognize the speaker's outlook. Trying to put yourself in the other person's shoes will make it easier for someone to express their opinion firmly.

This study also captures the characteristics of respondents, because several references explain that the ability to communicate assertively is associated to gender, educational status, birth order of participants, place of residence and parents' employment status. These variables are related to the attributes attached to the ability to communicate assertively. However, there will be an influence of family parenting on the development of family members, including in terms of communication. Adolescents who live with their families, with good economic conditions and good educational status are likely to experience good physical, social and emotional development. Good family resilience can prevent cyber bullying, because teenagers have gotten their needs from the family. Several previous studies have also emphasized the importance of the role of family and family in contributing to the formation of cyber bullying behavior (12-14). An external issue connected to the prevalence of cyber bullying is the level of education. This is possible because they are often exposed and have more assignments to do compare to students. In adolescents who are not used to communicating assertively, the vent of frustration will be directed at others as a result of the

\section{REFERENCES}

1. Rani S. Assertive Behaviour and Self Esteem Among Adolescent Girls. Indian Journal of Psychiatric Nursing. 2017; 13(1): 19-23.

2. Darjan I, Negru M, and Ilie D. Self-Esteem - The Decisive Difference Between Bullying and Asertiveness in Adolescence? Journal of Educational Sciences. 2020; 41(1): 19-34.

3. Kethsiyal. A Study to Evaluate the Effectiveness of Assertiveness Training on Low Self Esteem among Early Adolescent Girls ( Age Group between 13-15 years ) at Selected Schools in Dindigul District. [Dissertation]. Tamil Nadu Dr. M.G.R. Medical University, Chennai. 2016.

4. Muñoz-López MÁ and Hernández-Pozo M R. Software Development to Increase Coping Skills in Adolescents. Journal of Behavior, Health \& Social Issues. 2017; 9(1): 7-12.

5. Elbedour S, Alqahtani S, Rihan IES, Bawalsah JA, Booker-Ammah B, and Turner JF. Cyberbullying: Roles of School Psychologists And School Counselors In Addressing A Pervasive Social Justice Issue. Children and Youth Services Review. 2020; 109: 104720.

6. Zottis GAH, Salum GA, Isolan LR, et al. Associations Between Child Disciplinary Practices and Bullying Behavior in Adolescents. Jornal de Pediatria. 2014; 90(4): 408-414.

7. Reed P and Saunders J. Sex Differences in Online inability to cope with stress. This condition generally occurs if they are required to work on tasks in groups. Uncomfortable conditions resulted in the emergence of acts of intimidation of friends in the group who did not obey the order of the bully. The approach that is also important to remark is that the youth group approach will be easier if it is done through peers (37).

Cyber bullying is a psychological problem that is very complex and afflicts many adolescents with various causes. Family has a very important role in preventing bullying behavior and forming patterns of communication and positive behavior. Open communication between parents and educational institutions is opened to create policies that are able to monitor adolescent development stages optimally. Open communication concerning parents and educational institutions is very essential to establish togetherness in realizing the development of adolescents. An agreement is needed in order to create a policy to monitor the development of adolescents in responding to the unavoidable advances in communication technology. It is recommended to apprehend and investigate the importance on selfawareness, foster empathy and conflict resolution consistently and continuously.

\section{ACKNOWLEDGEMENT}

We would like to thank the Director of Politeknik Kesehatan Palembang for all the guidance, direction and facilitation in the implementation of this research. We also thank other parties who contributed to the study.

Assertive Self-Presentation Strategies. Personality and Individual Differences. 2020; 166: 110214.

8. Hymel S and Bonanno RA. Moral Disengagement Processes in Bullying. Theory Into Practice. 2014; 53(4): 278-85.

9. Peneva I and Mavrodiev S. A Historical Approach to Assertiveness. Psychological Thought. 2013; 6(1): 3-26.

10. Parray WM, Ahirwar Ghooman, and Sanjay K. A Study in Assertiveness among Rural Adolescents. International Journal of Research and Analytical Reviews. 2018; 5(4): 2348-2350.

11. Babaei M, Mohammadian M, Abdollahi M, and Hatami A. Relationship between Big Five Personality Factors, Problem Solving and Medical Errors. Heliyon. 2018; 4(9): e00789.

12. López-Meneses E, Vázquez-Cano E, González-Zamar MD, and Abad-Segura E. Socioeconomic Effects in Cyberbullying: Global Research Trends in the Educational Context. International Journal of Environmental Research and Public Health. 2020; 17(12): 1-29.

13. Tiffany F. Cyberbullying: A Narrative Review. Journal of Addiction Therapy and Research. 2018; 2(1): 10-27.

14. Livazović $\mathrm{G}$ and Ham E. Cyberbullying and Emotional Distress in Adolescents: The Importance of Family, Peers and School. Heliyon. 2019; 5(6): e01992.

15. Sharma D, Kishore J, Sharma N, and Duggal M. 
Aggression in Schools: Cyberbullying and Gender Issues. Asian Journal of Psychiatry. 2017; 29: 142-145.

16. Li Q. Cyberbullying in Schools: A Research of Gender Differences. School Psychology International. 2006;27(2): 157-170.

17. Wiguna $\mathrm{T}$, Irawati Ismail $\mathrm{R}$, Sekartini $\mathrm{R}$, et al. The Gender Discrepancy in High-Risk Behaviour Outcomes in Adolescents Who Have Experienced Cyberbullying in Indonesia. Asian Journal of Psychiatry. 2018; 37: 130-135.

18. Balakrishnan V and Fernandez T. Self-Esteem, Empathy and Their Impacts on Cyberbullying Among Young Adults. Telematics and Informatics. 2018; 35(7): 2028-3207.

19. Messias E, Kindrick K, and Castro J. School Bullying, Cyberbullying, or Both: Correlates of Teen Suicidality in the 2011 CDC Youth Risk Behavior Survey. Comprehensive Psychiatry. 2014; 55(5): 1063-1068.

20. Palermiti AL, Servidio R, Bartolo MG, and Costabile A. Cyberbullying and Self-Esteem: An Italian Study. Computers in Human Behavior. 2017; 69: 136-141.

21. Tokunaga RS. Following You Home From School: $A$ Critical Review And Synthesis of Research On Cyberbullying Victimization. Computers in Human Behavior. 2010; 26(3): 277-287.

22. Langos C. Cyberbullying: The Challenge to Define. Cyberpsychology, Behavior, and Social Networking. 2012; 15(6): 285-289.

23. Baldry AC, Farrington DP, and Sorrentino A. "Am I at Risk of Cyberbullying"? A Narrative Review and Conceptual Framework for Research on Risk of Cyberbullying and Cybervictimization: The Risk and Needs Assessment Approach. Aggression and Violent Behavior. 2015; 23: 36-51.

24. Pérez-Martínez V, Sanz-Barbero B, Ferrer-Cascales $\mathrm{R}$, et al. The Role of Social Support in Machismo and Acceptance of Violence Among Adolescents in Europe. Lights4Violence Baseline Results. Journal of Adolescent Health. 2020; 68(5); 922-927.

25. Burešová I, Vrbová $M$, and Čerňák M. Personality Characteristic of Adolescent Self-Harmers. Procedia - Social Behaviora Sciences. 2015; 171: 1118-1127.

26. Albritton A. Emotions in the Ether: Strategies for Effective Emotional Expression in Text-Messages.
Journal of Communication Media Technologiues. 2019; 7(2): 50-58.

27. Tran CV, Ngoc NPH, Weiss B, et al. Definition and Characteristics of "Cyberbullying" among Vietnamese Students. VNU Journal of Science: Education Research. 2018; 34(4): 1-10.

28. Sittichai $R$ and Smith PK. Bullying In South-East Asian Countries: A Review. Aggression and Violent Behavior. 2015; 23: 22-35.

29. Navarro R, Yubero S, and Larrañaga E. Cyberbullying Victimization and Fatalism in Adolescence: Resilience as a Moderator. Children and Youth Services Review. 2018; 84: 215-221.

30. Moksnes UK and Reidunsdatter RJ. Self-Esteem and Mental Health in Adolescents - Level and Stability During a School Year. Norks Epidemiology. 2019; 28(1-2): 59-67.

31. Larsen KL and Jordan SS. Assertiveness Training. In: Virgil Zeigler-Hill and Todd K. Shackelford (Eds) Encyclopedia of Personality and Individual Differences. Swiss: Springer, Cham: 2017; pp. 1-4.

32. Pfafman T. Assertiveness. In: Virgil Zeigler-Hill and Todd K. Shackelford (Eds) Encyclopedia of Personality and Individual Differences. Swiss: Springer, Cham: 2017.

33. Parray WM and Kumar S. Assertiveness among Undergraduate Students of the University. The International Journal of Indian Psychology. 2017; 4(1): 1-10.

34. Bhardwaj $\mathrm{H}$ and Viswash MG. Level of Assertiveness Among Adolescent's Students: A Review Based Literature. International Journal of Avanced Scientific Research. 2019; 4(2): 49-52.

35. Asrowi and Barida M. The Effectiveness of Asserive Training to Increase the Communication Skills of High School Students in Surakarta. DIJE. 2013; 1: 111.

36. Olweus D and Limber SP. Some Problems with Cyberbullying Research. Current Opinion in Psychology. 2018; 19(17): 139-143.

37. Hancock JT, Landrigan C, and Silver C. Expressing Emotion in Text-Based Communication. Proceedings of the SIGCHI Conference on Human Factors in Computing Systems. San Jose, April 28-May 3, 2007; p. 929-932. 